\title{
Role of cyclooxygenase-2 in Trypanosoma cruzi survival in the early stages of parasite host-cell interaction
}

\author{
Karen CM Moraes ${ }^{1 /+}$, Lívia F Diniz² ${ }^{2}$ Maria Terezinha Bahia ${ }^{2}$ \\ 'Laboratório de Biologia Molecular, Departamento de Biologia, Instituto de Biociências, Universidade Estadual Paulista Júlio de Mesquita Filho, \\ Rio Claro, SP, Brasil '2Laboratório de Doença de Chagas, Departamento de Ciências Biológicas, \\ Núcleo de Pesquisa em Ciências Biológicas, Universidade Federal de Ouro Preto, Ouro Preto, MG, Brasil
}

Chagas disease, caused by the intracellular protozoan Trypanosoma cruzi, is a serious health problem in Latin America. During this parasitic infection, the heart is one of the major organs affected. The pathogenesis of tissue remodelling, particularly regarding cardiomyocyte behaviour after parasite infection and the molecular mechanisms that occur immediately following parasite entry into host cells are not yet completely understood. When cells are infected with $\mathrm{T}$. cruzi, they develop an inflammatory response, in which cyclooxygenase-2 (COX-2) catalyses ratelimiting steps in the arachidonic acid pathway. However, how the parasite interaction modulates COX-2 activity is poorly understood. In this study, the H9c2 cell line was used as our model and we investigated cellular and biochemical aspects during the initial 48 h of parasitic infection. Oscillatory activity of COX-2 was observed, which correlated with the control of the pro-inflammatory environment in infected cells. Interestingly, subcellular trafficking was also verified, correlated with the control of Cox-2 mRNA or the activated COX-2 protein in cells, which is directly connected with the assemble of stress granules structures. Our collective findings suggest that in the very early stage of the T. cruzi-host cell interaction, the parasite is able to modulate the cellular metabolism in order to survives.

Key words: cardiac cells - Chagas disease - enzyme activity - fluorescence microscopy pro-inflammatory process - subcellular trafficking

Chagas disease, caused by the intracellular protozoan pathogen Trypanosoma cruzi, is a leading cause of cardiomyopathy and heart failure in Latin America. It is estimated that more than eight million people are affected by the parasite and thousands of others are at potential risk of infection (WHO 2013). T. cruzi induces multiple responses in the heart, which is a critical organ affected by this infection and its pathology in the host (Zhang \& Tarleton 1999). The initial cardiomyocyte response to the T. cruzi is fundamental to establish the infection and is dependent on the activation of host cell signalling pathways, which involves immediate activation of kinases and phosphatases as well as intracellular $\mathrm{Ca}^{2+}$ mobilisation and even changes in the pattern of gene expression (Burleigh \& Woolsey 2002, Burleigh \& Soldati 2008). The complexity of T. cruzi cellular invasion and survival is considered a challenge. However, because it is possible to cure the disease if treatment is initiated soon after infection, understanding the molecular mechanisms that support the initial steps of parasite survival will contribute to the development of innovative therapies.

Considerable research has been conducted to clarify cardiomyocyte behaviour after parasitic infection (Pe-

doi: 10.1590/0074-02760140311

Financial support: FAPEMIG (CBB-APQ-02351-10, CBB-APQ01700-11), CNPq (475586/2009-3), PROPE-UFOP

+Corresponding author: KarenMoraes_33@hotmail.com

Received 23 August 2014

Accepted 18 March 2015 tersen \& Burleigh 2003, Calvet et al. 2012, Corral et al. 2013). However, the molecular mechanisms that occur immediately after parasite entry into host cells are still poorly understood. It is well established that cardiomyocytes are specialised cells that promptly respond to a variety of stimuli (Steinberg 2000, Burleigh \& Soldati 2008). During heart infection, T. cruzi triggers myocardial overexpression of pro-inflammatory mediators and eicosanoids in the plasma of mice, which correlates with the development of acute myocarditis (Huang et al. 1999, Mukherjee et al. 2011). Eicosanoids are described as a family of molecules that are involved in many biological mechanisms and tissue homeostasis (Haeggstrom et al. 2010). Eicosanoids are derived from the arachidonic acid (AA) pathway and in this biochemical pathway, cyclooxygenase-2 (COX-2), catalyses the rate-limiting steps of eicosanoid biosynthesis (Prior-Curtis 2004). Nevertheless, despite all efforts to understand the mechanistic function of COX-2 and its metabolites in parasitic disease, it is still not clear how the functional activity of the enzyme is modulated. However, following the detection of prostaglandin (PG) synthases in Trypanosoma brucei, Leishmania and even T. cruzi (Sage et al. 1981, Kubata et al. 2002, Kabututu et al. 2003), the production of the prostanoids has been investigated in parasites. In T. cru$z i$, in particular, there is evidence demonstrating that the parasite preferentially synthesises thromboxane (Ashton et al. 2007) and the release of eicosanoids contributes to invasion and survival in the host (Sterin-Borda et al. 1996, Freire-de-Lima et al. 2000, Mukherjee et al. 2011). In addition, more recent studies have demonstrated that T. cruzi is also capable of metabolizing AA (Livore et al. 2007, Machado et al. 2011), which reinforces the relevance of this molecular pathway for the parasite. 
Focusing on the inflammatory mechanisms of Chagas disease, several studies have demonstrated the pathological and physiological effects caused by $T$. cruzi infection in the heart and molecular analysis has found a disruption of cellular homeostasis in the presence of the parasite. An interesting cardiac gene expression profile analysis revealed a broad range of molecular changes in human Chagas cardiomyopathy including a modulatory effect of the parasite on the immune response, lipid metabolism, pathological hypertrophy and even on the apoptosis-related RNA-binding protein (NAPOR-3) gene (Cunha-Neto et al. 2005). NAPOR-3, also known as CUGBP2, is an RNA-binding protein that is able to bind to the adenylate-uridylate-rich elements (ARE) in the 3'-UTR of Cox-2 mRNA, which inhibits its translation and its functional activity in a cell. Various studies (Mukhopadhyay et al. 2003a, b, Murmu et al. 2004) have demonstrated the existence of a regulatory loop between COX-2 and the RNA-binding protein CUGBP2. However, this binding activity depends on the stimuli to which cells are exposed (Xu et al. 2007). Based on such observations, we aimed to investigate the initial molecular aspects of $T$. cruzi invasion and interactions in $\mathrm{H} 9 \mathrm{c} 2$ cells, a cardiac-derived cell line, focusing our analyses on the mechanisms through which the COX-2 protein is regulated and whether CUGBP2 plays a function in this process. Here, we observed that within the first $48 \mathrm{~h}$ of infection, CUGBP2 acts as a co-factor of Cox-2 mRNA cellular trafficking, by controlling the pro-inflammatory cellular environment. Moreover, cellular assays show that $T$. cruzi elicits modulatory effects on cellular signalling, negatively modulating COX-2 protein activity through its accumulation in cellular granular structures. Oscillatory activity of COX-2 in infected cells could explain how the parasite brings the cell under its control in the initial acute phase of Chagas disease.

\section{MATERIALS AND METHODS}

Cell culture - H9c2 (2-1) cells [American Type Culture Collection (ATCC): CRL-1446)] are an embryonic rat ventricular cell line. These cells were grown and maintained in Dulbecco's Modified Eagle Medium (DMEM) supplemented with $10 \%$ foetal bovine serum (FBS) and $100 \mu \mathrm{g} / \mathrm{mL}$ penicillin/streptomycin under an atmosphere of $5 \% \mathrm{CO}_{2}$ at $37^{\circ} \mathrm{C}$. All reagents were purchased from Life Technologies ${ }^{\mathrm{TM}}$ (Brazil). In the experimental control cell cultures, $10 \mu \mathrm{M}$ NS-398 (Cayman Chemical, USA), previously dissolved in dimethyl sulfoxide $(0.02 \% \mathrm{vol} /$ vol) (Meyer-Siegler 2001), was added to the media and the cells were finally incubated for up to $48 \mathrm{~h}$.

Parasite infection - T. cruzi (Y strain, DTUII) was propagated in monolayers of Vero cells (ATCC: CCL-81) in DMEM with $2 \%$ FBS and infective trypomastigotes were harvested as described previously (Petersen \& Burleigh 2003). Next, $1.5 \times 10^{7}$ parasites were incubated with $1.5 \times 10^{6} \mathrm{H} 9 \mathrm{c} 2$ cells for $2 \mathrm{~h}$ at $37^{\circ} \mathrm{C}$ under $5 \% \mathrm{CO}_{2}$ to allow parasite-cell interaction. The remaining extracellular parasites were aspirated and the cells were extensively washed with phosphate-buffered saline (PBS) $(2.7 \mathrm{mM}$ $\mathrm{KCl}, 1.5 \mathrm{mM} \mathrm{KH}_{2} \mathrm{PO}_{4}, 137 \mathrm{mM} \mathrm{NaCl}$ and $8 \mathrm{mM} \mathrm{Na}_{2} \mathrm{H}-$
$\mathrm{PO}_{4}, \mathrm{pH}$ 7.4), after which fresh medium was added to the culture. Flasks containing cellular cultures were then incubated for another $2,6,12,24$ or $48 \mathrm{~h}$, as previously described, and cells were finally collected. The uninfected groups of cells were used as control in the assays.

$R N A$ isolation and quantitative reverse transcription-polymerase chain reaction ( $q R T-P C R$ ) - Total RNA was extracted from $1.5 \times 10^{6}$ cells either infected or not with $T$. cruzi using the TRIZOL ${ }^{\circledR}$ Reagent (Life Technologies $^{\mathrm{TM}}$ ). Two micrograms of each RNA sample were reverse-transcribed into first-strand cDNA using Cloned AMV Reverse Transcriptase (Life Technologies ${ }^{\mathrm{TM}}$ ), following the instructions of the supplier. All reverse-transcribed reactions were analysed through real-time PCR using SYBR Green Master Mix (Life Technologies ${ }^{\mathrm{TM}}$, USA) in an ABI 7300 Sequence Detection System (Applied Biosystems). The reactions were run in triplicate and mRNA expression was normalised to the reference gene $\beta$-actin. The specific sets of primers used in these analyses were as follows: $\beta$-actin, 5'-TGGTGGGTATGGGTCAGAAG and 5'-CAATGCCGTGTTCAATGG, CUGBP2, 5'-AACAGGGAAGGCAGAGGAG and 5'-GGGCATTAGTGGAAGAAACG, and $C O X-2$, 5'-CAGCCCACCAACTTACAATG and 5'-CATCAGCCACAGGAGGAAG. The results were quantified as threshold cycle $(\mathrm{Ct})$ values defined as the $\mathrm{Ct}$ of PCR at which the amplified product is first detected and defined as relative gene expression (the ratio of target/control) and the $2{ }^{\Delta \Delta \mathrm{CT}}$ method was applied.

Western blot (WB) analysis - Whole cell extracts were prepared according to Sambrook et al. (2001). Equal amounts of protein $(50 \mu \mathrm{g})$ were electrophoresed in $10 \%$ polyacrylamide gels and then electrotransferred to polyvinylidene fluoride membranes. The membranes were immunoblotted overnight with rabbit anti-CUGBP2 (Sigma-Aldrich, USA), mouse anti-COX-2 (Cayman Chemical) or rabbit anti- $\beta$ actin (Santa Cruz Biotech Inc, USA) polyclonal antibodies, followed by $2 \mathrm{~h}$ of incubation with a horseradish peroxidase-conjugated goat anti-rabbit antibody or anti-mouse (Cayman Chemical). Immunoreactive bands were visualised with a chemiluminescent detection kit (ECL ${ }^{\mathrm{TM}}, \mathrm{GE}$ Healthcare) and exposed to Hyperfilm (GE Healthcare). The bands were quantified with Quantit One Software (Biorad).

Interleukin (IL)-1 $\beta$ and prostaglandin E2 (PGE2) immunoassays - Cellular culture supernatants were used in the immunoassays. The secreted cytokine IL-1 (Cayman Chemical) and the PGE2 (Cayman Chemical) were measured in $50 \mu \mathrm{L}$ of the supernatants using specific ELISA kits, as directed by the manufacturer. The assays were analysed with a microplate reader (Packard Instrument Company Inc, USA).

RNA in situ hybridisation and co-immunostaining Fluorescence microscopy analyses were performed on $1.5 \times 10^{4}$ cells grown on sterile coverslips. After extensive washes in PBS, cells were fixed in 3.8\% paraformaldehyde containing $0.2 \%$ Triton X-100 (Sigma-Aldrich) for 7 min at $37^{\circ} \mathrm{C}$ and subjected to immunostaining. To verify cellular behaviour after parasite infection, the cytoskel- 
eton was labelled in a $1 \%$ bovine serum albumin (BSA) solution containing $100 \mu \mathrm{g} / \mathrm{mL}$ of phalloidin-tetramethylrhodamine B isothiocyanate (Sigma-Aldrich) for $1 \mathrm{~h}$ and the nuclei were counterstained in a solution of $3.33 \mathrm{ng} / \mathrm{mL}$ 4',6 diamino-2-phenylindole (DAPI) (Sigma-Aldrich). For RNA labelling, we adapted the methodology described in Taneja (1998). Following permeabilisation, the cells were pre-hybridised in a $2 \mathrm{x}$ saline-sodium citrate (SSC) solution $(1 \times \mathrm{SSC}=0.15 \mathrm{M} \mathrm{NaCl}$ and $0.015 \mathrm{M}$ sodium citrate, $\mathrm{pH} 7.0$ ) containing $40 \%$ formamide for $10 \mathrm{~min}$ at room temperature. Next, the cells were hybridised for 2 $\mathrm{h}$ at $37^{\circ} \mathrm{C}$ with an RNA-COX-2 probe labelled at the 5'position with Alexa-Fluor 610 (5'-CATTGTAAGTTGGTGGGCTG) (Life Technologies ${ }^{\mathrm{TM}}$ ) at a final concentration of $1 \mathrm{ng} / \mu \mathrm{L}$ in a solution containing $40 \%$ formamide, $2 \mathrm{x}$ SSC and $0.2 \%$ BSA. After hybridisation, the cells were washed once with $40 \%$ formamide, $1 \times$ SSC for 30 min at $37^{\circ} \mathrm{C}$ and twice with $1 \times \mathrm{SSC}$ at room temperature for 30 min. Next, co-immunostaining was performed, in which the cells were incubated with the primary antibody antiCUGBP2 (1:100) overnight at $4^{\circ} \mathrm{C}$. After extensive washes in PBS at room temperature, a secondary goat anti-rabbit IgG antibody (Life Technologies ${ }^{\mathrm{TM}}$ ) conjugated with fluorescein isothiocyanate (FITC) was added (1:50), followed by incubation for $1 \mathrm{~h}$ at room temperature. For eukaryotic initiation factor (eIF4G) (Cell Signalling, USA) labelling, the same procedure was followed and a secondary goat anti-rabbit IgG antibody conjugated with cyanine 5 (Kirkegaard \& Perry Laboratories, USA) was used. Cells on coverslips were finally counterstained with DAPI and mounted on slides using $200 \mathrm{mM}$ propyl gallate (SigmaAldrich) in 90\% glycerol. For COX-2 labelling, cells on coverslips were incubated with anti-COX-2 primary antibody (1:25) and a secondary antibody conjugated with FITC was used. These cells where then co-immunostained for eIF4G as described above and the nuclei were visualised with DAPI counterstaining. The cells were subsequently mounted on slides and were all subjected to microscopic analysis. Images were obtained with a Leica DMLB photomicroscope equipped with an HBO $100 \mathrm{~W}$ mercury lamp and the corresponding filter sets. The assays were performed in quadruplicate and statistical analyses were performed by counting 100 cells.

Recombinant protein, co-immunoprecipitation (CoIP) and formaldehyde RNA cross-linking - CUGBP2 was amplified by RT-PCR and cloned into pGEX-2T. GST-tagged CUGBP2 was produced in BL21 (DE3) cells and purified on glutathione sepharose 4B [recombinant (rCUGBP2)]. For the Co-IP assays of CUGBP2 and Cox-2 mRNA, $60 \mu \mathrm{L}$ of $\mathrm{H} 9 \mathrm{c} 2$ cell extract was first pre-cleared by the incubation with $20 \mu \mathrm{L}$ of $50 \%$ slurry of protein A sepharose for $30 \mathrm{~min}$ at $4^{\circ} \mathrm{C}$. The precleared extract was then incubated with $\alpha-C U G B P 2$ and $\alpha$-normal serum in $1 \mathrm{~mL}$ of buffer B (300 mM HEPES at $\mathrm{pH} 7.9,1.5 \mathrm{mM} \mathrm{MgCl} 2,10 \mathrm{mM} \mathrm{KCl}$ ) containing 0.5 $\mathrm{mM}$ DTT for $2 \mathrm{~h}$ at $4^{\circ} \mathrm{C}$. After this first incubation, 18 $\mathrm{mL}$ of $50 \%$ slurry of protein A sepharose was added; the mixture was incubated for another hour at $4^{\circ} \mathrm{C}$. The beads were then washed three times with NET 2 buffer (50 mM Tris at pH 7.6, $75 \mathrm{mM} \mathrm{NaCl}, 0.05 \%$ Nonidet
$\mathrm{P}-40$ ) for $5 \mathrm{~min}$ at $4^{\circ} \mathrm{C}$ and bound proteins were eluted by addition of $2 \mathrm{x}$ sodium dodecyl sulfate (SDS) gel loading buffer and boiling for $5 \mathrm{~min}$. Following centrifugation, the supernatant was collected and proteins separated on a $10 \%$ SDS polyacrylamide gel. CUGBP2 was detected by WB using rabbit anti-CUGBP2 antibody as described above. For the analysis of cross-linked RNA, previously to the immunoprecipitation procedure, Cox-2 mRNA was incubated with $\mathrm{H} 9 \mathrm{c} 2$ cell extract and cross-linked with $1 \%$ of formaldehyde. For that, cells were incubated with $1 \%$ formaldehyde at room temperature under mild agitation for $7 \mathrm{~min}$ and then pelleted at $1,800 \mathrm{~g}$ and reverse-transcribed for $3 \mathrm{~min}$, resulting in $10 \mathrm{~min}$ exposure to formaldehyde. The cross-linking was stopped by adding glycine to a final concentration of $0.125 \mathrm{M}$. Cells were transferred to a smaller tube, spun, washed once in $1.25 \mathrm{M}$ glycine/PBS and used in Co-IP assays as described above. After the final washes of the beads with NET Buffer, PBS was added to the beads and the native and formaldehyde-fixed RNA samples were then heated at $70^{\circ} \mathrm{C}$ for $30 \mathrm{~min}$. The RNAs were then used in RT reactions followed by qPCR analyses.

COX-2 enzyme activity - Pellets from $1.5 \times 10^{8}$ cells were homogenised in $50 \mu \mathrm{L}$ of cold buffer $(0.1 \mathrm{M}$ Tris$\mathrm{HCl}, \mathrm{pH} 7.8$, containing $1 \mathrm{mM}$ ethylenediamine tetraacetic acid and centrifuged at $10,000 \mathrm{~g}$ for $15 \mathrm{~min}$ at $4^{\circ}$. The supernatants were used to measure COX-2 activity according to the instructions of the manufacturer of the COX Activity Assay (Cayman Chemical). Peroxidase activity was assayed colourimetrically by monitoring the appearance of oxidised $\mathrm{N}, \mathrm{N}, \mathrm{N}, \mathrm{N}^{\prime}$-tetramethyl- $p$ phenylenediamine (TMPD) at $590 \mathrm{~nm}$. COX-2 activity was assessed using the selective COX-1 inhibitor SC560. COX-2 activity was expressed as the rate of oxidation of TMPD in U/mL ( $\mathrm{nmol} / \mathrm{min} / \mathrm{mL})$.

Graphs and statistical analyses - Values from three independent assays were employed for analysis and graphs were generated using Graph Pad Prism ${ }^{\circledR}$ 5. The differences between the control and treated groups were also measured using ANOVA followed by Dunnett's test. Significance was set at $\mathrm{p}<0.05, \mathrm{p}<0.01$ and $\mathrm{p}<0.001$.

\section{RESULTS}

T. cruzi invasion and its modulatory effect on cellular metabolism - T. cruzi invasion and survival in host cells are critical steps in the establishment of infection. Thus, we first investigated cellular behaviour after parasite interaction. After 24 and 48 h of parasitic infection, fluorescence microscopy analyses were performed (Fig. 1A). No cytoskeletal damage was observed at the investigated time points and amastigotes were clearly observed in infected cells. A 30\% rate of cellular infection by $T$. cruzi was found in the cultures. The lower rates of infection could be correlated with the parasite infection load (Borges et al. 2013). However, in the life cycle of T. cruzi in a cell, inflammatory mediators and eicosanoids are frequently found and strong evidence supports that those cellular mediators are essential for the progression of the disease (Sterin-Borda et al. 1996, Mukherjee et al. 2011). As described in Petersen and Burleigh (2003), some pro- 
A

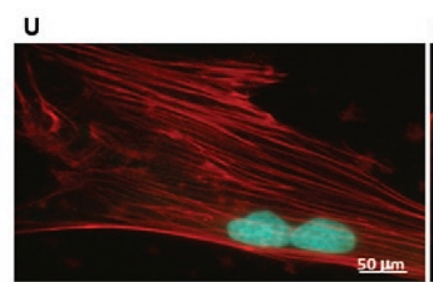

$24 \mathrm{~h}$

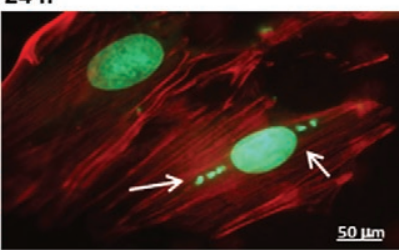

$48 \mathrm{~h}$

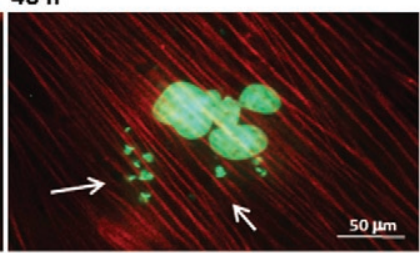

B
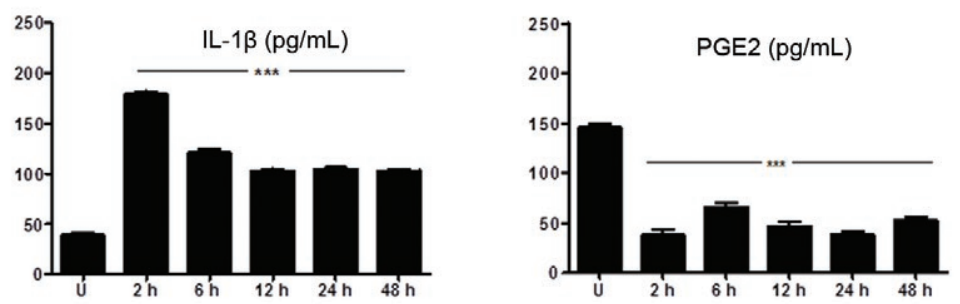

Fig. 1: biological effects of the Trypanosoma cruzi Y strain interaction and infection in H9c2 cells. The cells were grown and infected or not with the parasite and the initial $48 \mathrm{~h}$ of parasitic infection were investigated. A: infected and uninfected (U) cells were analysed via fluorescence microscopy. The nuclear material and cytoskeleton were labelled with 4',6 diamino-2-phenylindole and phalloidin-tetramethylrhodamine B isothiocyanate. Arrows point to amastigotes. Bars $=50 \mu \mathrm{m}$; B: cellular metabolites such as the pro-inflammatory mediator interleukin (IL)-1 $\beta$ and the eicosanoid prostaglandin E2 (PGE2) produced by H9c2-infected cells were measured and the results were plotted in graphs. The presented values are the average of three independent experiments and the error bars represent the standard deviation of the mean. ANOVA testing showed significant differences between the control and cell samples and the significance level was set at $\mathrm{p}<0.001(* * *)$.

inflammatory elements secreted by the infected cultures synchronise cell response in culture and they are also considered important mediators of cellular hypertrophy in Chagas disease. Thus, despite any cytoskeletal damage, we measured the cellular metabolites IL-1 $\beta$ and PGE2 in parasite-infected and uninfected cells. The production of IL-1 $\beta$ and PGE2 was analysed and the results are presented in Fig. 1B. At $2 \mathrm{~h}$, increased production of IL-1 $\beta$ was observed $(179.18 \mathrm{pg} / \mathrm{mL})$ compared with the uninfected cell culture $(39.10 \mathrm{pg} / \mathrm{mL})$, with the levels decreasing to approximately $100 \mathrm{pg} / \mathrm{mL}$ in the succeeding time-points. PGE2 levels in T. cruzi-infected cells were down-regulated at all investigated time-points compared with the levels in uninfected cultures (145.83 $\mathrm{pg} / \mathrm{mL}$ ). This prostanoid was chosen based on the relevance of PGE2 to the parasite infection (Sterin-Borda et al. 1996, Abdalla et al. 2008) and by the fact that H9c2 responds to a different set of stimuli similar to an adult cardiomyocyte (Kimes \& Brandt 1976); in addition, there is evidence that describes the production of PGE2 by such cells, when COX-2 is activated (Lu \& Choy 2004, Kwak et al. 2010, Sharma et al. 2013, Sakane et al. 2014). In the analysed time-points (control, 2, 6, 12 , 24 and $48 \mathrm{~h}$ ), PGE2 levels oscillated and were reduced when compared with the control $(\mathrm{p}<0.001): 38.08 \mathrm{pg} /$ $\mathrm{mL}(2 \mathrm{~h}), 66.26 \mathrm{pg} / \mathrm{mL}$ (6 h), $47.31 \mathrm{pg} / \mathrm{mL}$ (12 h), 39.11 $\mathrm{pg} / \mathrm{mL}(24 \mathrm{~h})$ and $52.64 \mathrm{pg} / \mathrm{mL}(48 \mathrm{~h})$. On measurement PGE2 content in the cells, correlation was found with COX-2 activity oscillatory pattern in most of the timepoint investigated, as later described. This oscillatory pattern, at the initial stage of T. cruzi infection, may be an advantage to the parasite infection, which probably avoids cellular death. Together, the results corroborate the modulatory effect of T. cruzi on the metabolism of infected $\mathrm{H} 9 \mathrm{c} 2$ compared with the uninfected cells.

\section{Molecular connections between $C O X-2$ and CUGBP2} in T. cruzi-infected cells - The impetus for the study presented here was the findings of Cunha-Neto et al. (2005), who observed an increased level of Cugbp2 mRNA transcription. In addition, the reported connections between CUGBP2 and Cox-2 mRNA in the control of pro-inflammatory stimuli (Mukhopadhyay et al. 2003a, b, Murmu et al. 2004, Xu et al. 2007, Moraes et al. 2013) led us to analyse the molecular connections between these two molecules in T. cruzi-infected cells. The results presented in Fig. 2A revealed a $\sim 57 \%$ increase in COX-2 protein levels at the $2 \mathrm{~h}$ time-point compared with the uninfected cells, which decreased thereafter. At the $48 \mathrm{~h}$ time-point, the concentration of cyclooxygenase protein returned to its basal level (uninfected cells). For CUGBP2, the highest protein level in $\mathrm{H} 9 \mathrm{c} 2$ cells was observed after $6 \mathrm{~h}$ of parasitic infection $(\sim 126 \%$ higher than the level found in uninfected cells), which decreased in the succeeding time-points. The same oscillatory pattern was observed for Cox-2 and Cugbp2 mRNA expression (Fig. 2B). However, the transcriptional level of Cox-2 was 6.72 times higher than the level found in uninfected culture in the $2 \mathrm{~h}$ time-point assay and the Cugbp2 mRNA level presented a 1.84-fold increase at $6 \mathrm{~h}$ time-point.

Next, the molecular connections between Cox-2 mRNA and the CUGBP2 protein in H9c2-infected cells were investigated with immunofluorescence analyses. Fig. 3A demonstrates that CUGBP2 preferentially co-localises to the cell nucleus (Roberts et al. 1997, Savkur et 
A

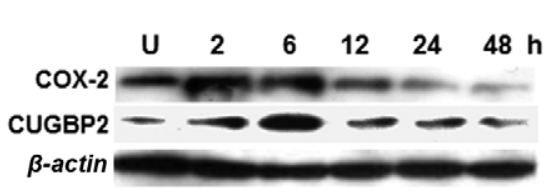

cox-2

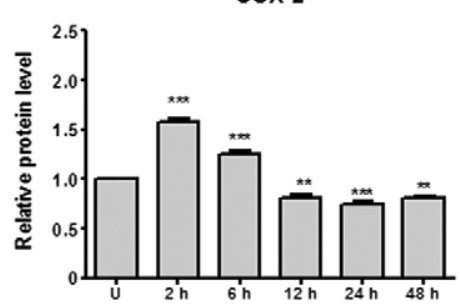

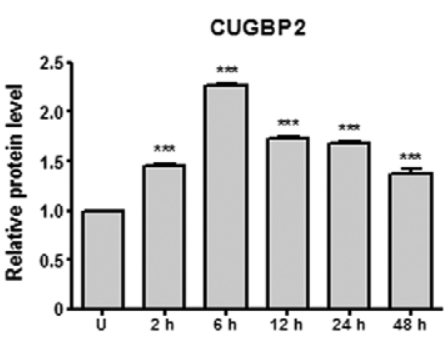

B
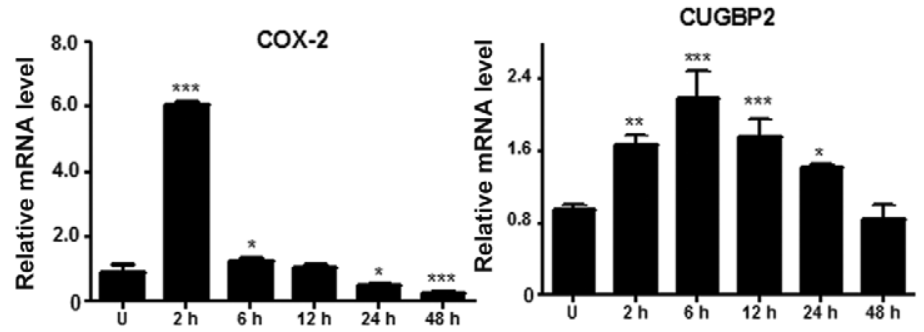

Fig. 2: regulatory connection between cyclooxygenase-2 (COX-2) and the RNA-binding protein CUGBP2 in H9c2 cell line. Cells were grown and infected or not with the parasite and the initial $48 \mathrm{~h}$ of parasitic infection were analysed. A: western blotting analyses of COX-2, CUGBP2 and the reference protein $\beta$-actin and their respective quantification; B: modulatory effect of the parasitic infection on the gene expression of Cox-2 and Cugbp2. Changes in mRNA levels were expressed as the relative fold change normalised to the reference gene $\beta$-actin. Error bars represent the standard deviation of the mean from three independent experiments. ANOVA testing showed significant differences between the control and cell samples and was set at $\mathrm{p}<0.05(*), \mathrm{p}<0.01\left({ }^{*}\right)$ and $\mathrm{p}<0.001(* * *)$; U: uninfected cultures.

al. 2001, Timchenko et al. 2001) and under a pro-inflammatory stimulus, CUGBP2 shuffling to the cytoplasm was correlated with the Cox-2 mRNA distribution, as previously described (Timchenko et al. 2001). More intense translocation of CUGBP2 from the nucleus to cytoplasmic structures defined as stress granules (SGs) (Kedersha et al. 2005, Gareau et al. 2011) was observed at the $2 \mathrm{~h}$ time-point during T. cruzi cellular infection, which corresponded to the highest transcriptional level of Cox-2 mRNA produced by the infected H9c2 cells. To confirm whether the subcellular structures observed under microscopy were real SGs, the eIF4G protein was positively labelled and visualised (Fig. 3A). In addition, CUGBP2 gene silencing was also performed in $\mathrm{H} 9 \mathrm{c} 2$ cells to verify the relevance of the protein in the molecular shuffling of messenger RNAs. However no single clone survived longer than $48 \mathrm{~h}$ (data not shown). Next, to corroborate the physical interaction of the above two molecules that support the molecular trafficking, Co-IP and formaldehyde RNA cross-linking were performed. The results presented in Fig. 3B demonstrated that CUG$\mathrm{BP} 2$ is present in $\mathrm{H} 9 \mathrm{c} 2$ cell extract and rCUGBP2 was used as positive control of the assay. To prove the physical interaction between the protein and Cox-2 mRNA, the messenger molecule was cross-linked to the protein before the Co-IP procedure. The linkage of the target RNA and CUGBP2 was verified in qPCR (Fig. 3C).

T. cruzi elicits modulatory effects on the activity and cellular distribution of the COX-2 protein - Next, to understand the effect of T. cruzi cellular infection on prostanoid production, COX-2 activity was measured. The results shown in Fig. 4A demonstrate that at the $2 \mathrm{~h}$ time- point, protein activity was almost abolished (a $\sim 96.1 \%$ reduction in COX-2 activity was observed, $0.011 \mathrm{U} /$ $\mathrm{mL})$ compared with the uninfected group $(0.265 \mathrm{U} / \mathrm{mL})$. However, after $6 \mathrm{~h}$ of parasitic infection, COX-2 activity reached the highest level observed in the assays $(\sim 0.468$ $\mathrm{U} / \mathrm{mL}$ ), which decreased to lower levels in the succeeding time-points analysed: $\sim 0.13 \mathrm{U} / \mathrm{mL}(12 \mathrm{~h})$ and $\sim 0.034 \mathrm{U} /$ $\mathrm{mL}(24 \mathrm{~h})$, respectively. At $48 \mathrm{~h}$, the activity of the protein returned to near its homeostatic level. All these changes in COX-2 activity were statistically significant with $\mathrm{p}<$ 0.001 . However, despite it is not possible to compare pg/ $\mathrm{mL}$ (PGE2) with $\mathrm{U} / \mathrm{mL}$ (COX-2 activity), the oscillatory pattern of COX-2 activity is quite similar to the PGE2 production, as mentioned in the previous section. The combined results suggest a positive interconnection of cellular mechanisms and reinforce dependence of PGE2 synthesis on COX-2 activity, as largely described (PriorCurtis 2004, Kim et al. 2014). In addition, fluorescence microscopy analyses demonstrated a nuclear distribution of the COX-2 protein at all investigated time-points. However, at the time-points at which COX-2 presented decreased activity $(2,12$ and $24 \mathrm{~h})$, the protein also colocalised at SG structures (Fig. 4B), which is identified by the co-immunostaining with the eIF4G protein.

NS-398 mimics the modulatory effect of T. cruzi on the activity and distribution of $\mathrm{COX}-2$ in $\mathrm{H} 9 \mathrm{c} 2$ cells - Considering the modulatory effects of $T$. cruzi on the activity and distribution of COX-2 in $\mathrm{H} 9 \mathrm{c} 2$ cells, we investigated the effect of NS-398, a selective COX-2 inhibitor, on this uninfected cardiac cell line. As observed in Fig. 5A, COX-2 protein and RNA levels increased when cells were treated with the COX-2 inhibitor. The highest expression level of 


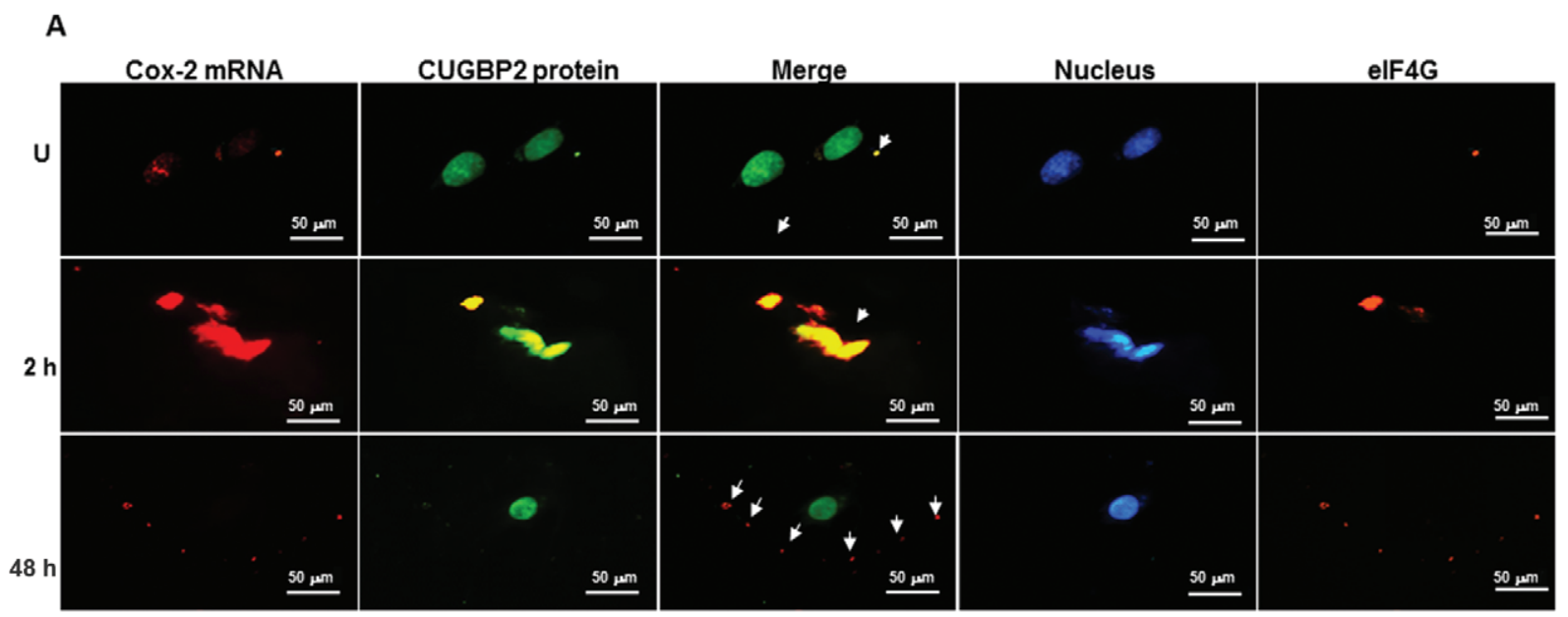

B

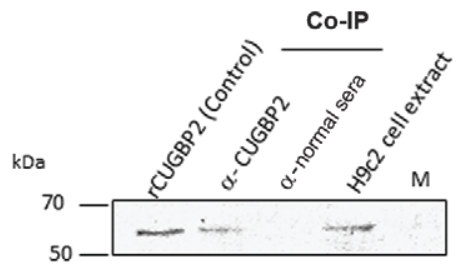

C

qPCR

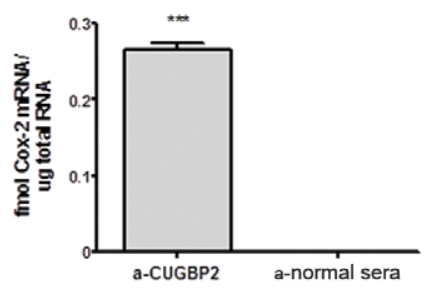

Fig. 3: molecular interaction between cyclooxygenase-2 (Cox-2) mRNA and CUGPP2 protein. A: fluorescence microscopy analyses of the cross-talk between Cox-2 mRNA and CUGBP2 in H9c2 cells after parasitic infection. The CUGBP2 protein (fluorescein isothiocyanate labelled) localised preferentially to the nucleus (4,6 diamino-2-phenylindole labelled) and co-localised in the cytoplasmic region with Cox-2 mRNA (Alexa Fluor labelled and indicated with arrowheads) and with eukaryotic initiation factor (eIF4G) (cyanine 5 labelled). Bars $=50 \mu \mathrm{m}$; B: co-immunoprecipitation (Co-IP) of CUGBP2 and Cox-2 mRNA in H9c2 cells followed by western blotting analyses (using total cell extract). Recombinant CUGBP2 (rCUGBP2) and total H9c2 extracts were used as control in the assay. The Co-IP precisely captured the protein from $\mathrm{H} 9 \mathrm{c} 2$ total cell extract and the molecules that bind to it; $\mathrm{C}$ : formaldehyde RNA cross-linking assay using Cox-2 mRNA and H9c2 cell extract was performed followed by the Co-IP to capture the molecules that binds to CUGBP2. Quantitative polymerase chain reaction (qPCR) quantified the total amount of Cox-2 mRNA that binds to CUGBP2 and error bars represent the standard deviation of the mean from three independent experiments. ANOVA testing showed significant differences between the control and cell samples and was set at $\mathrm{p}<0.001(* * *)$; M: marker.

COX-2 was observed at the $2 \mathrm{~h}$ time-point, with the protein level increasing by $\sim 56.6 \%$ and the RNA level increasing $\sim 7.62$ times when compared to untreated cells. At the succeeding time points, COX-2 protein and RNA gradually returned to close to their basal levels, considering the turnover rates. We further determined the effect of the drug on $\mathrm{COX}-2$ activity in $\mathrm{H} 9 \mathrm{c} 2$ cells. A more pronounced negative effect was observed after $2 \mathrm{~h}$ and $6 \mathrm{~h}$ of incubation of $\mathrm{H} 9 \mathrm{c} 2$ cells with the drug compared with the culture to which no chemicals were added $(\sim 0.323 \mathrm{U} / \mathrm{mL}$, untreated). The corresponding protein activities were $\sim 0.011 \mathrm{U} / \mathrm{mL}$ and 0.089 $\mathrm{U} / \mathrm{mL}$ respectively, which returned to near basal levels in the succeeding time-points. In addition, the effect of NS398 on prostanoid PGE2 synthesis in the uninfected H9c2 cells was analysed and the results demonstrated again a close connection between COX-2 activity and PGE2 production. In the investigated cellular cultures, the produc- tion of PGE2 was reduced by an average of $\sim 69.25 \%$ (30.75 $\mathrm{pg} / \mathrm{mL})$ and $\sim 65.08 \%(34.92 \mathrm{pg} / \mathrm{mL})$ at the $2 \mathrm{~h}$ and $6 \mathrm{~h}$ time-points, when compared with the untreated cells ( $\sim 146$ $\mathrm{pg} / \mathrm{mL}$ ). The basal levels being re-established thereafter, which suggests the lost of drug activity on cultures.

Based on these findings, we performed microscopy analyses (Fig. 5B) and COX-2 showed a mainly nuclear distribution in H9c2 cells. In NS-398-treated cells, granular structures containing COX-2 protein were also present at the specific time-points at which COX-2 was inactive ( $2 \mathrm{~h}$ and $6 \mathrm{~h}$ time-points). As observed previously, such granular structures correspond to SG structures based on positive co-immunostaining for the eIF4G protein. The investigated 12, 24 and $48 \mathrm{~h}$ time-point NS-398 -cellular treatment were not represented at Fig. 5, considering the extremely similar pattern of COX-2 protein and mRNA distribution found to the untreated cells. 


\section{A}

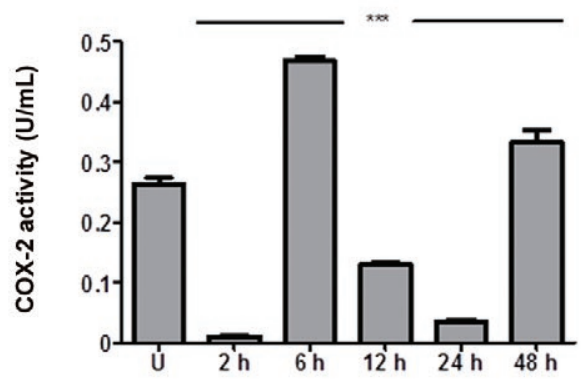

\section{B}

$\mathbf{U}$

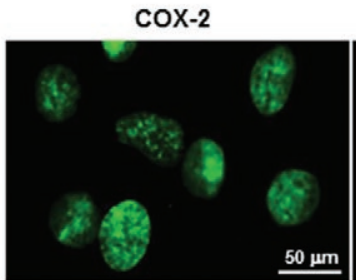

DAPI

Merge

elF4G

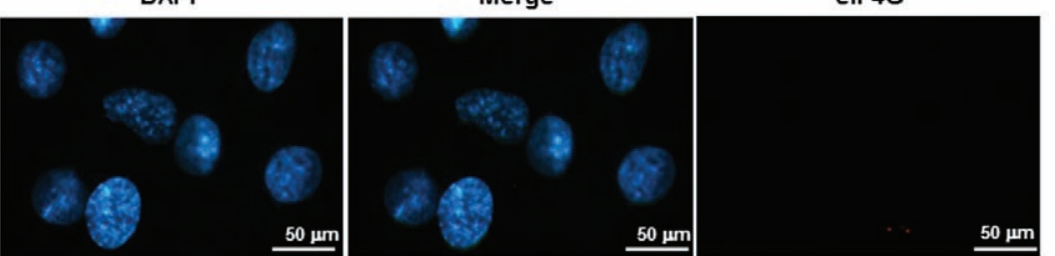

$2 \mathrm{~h}$
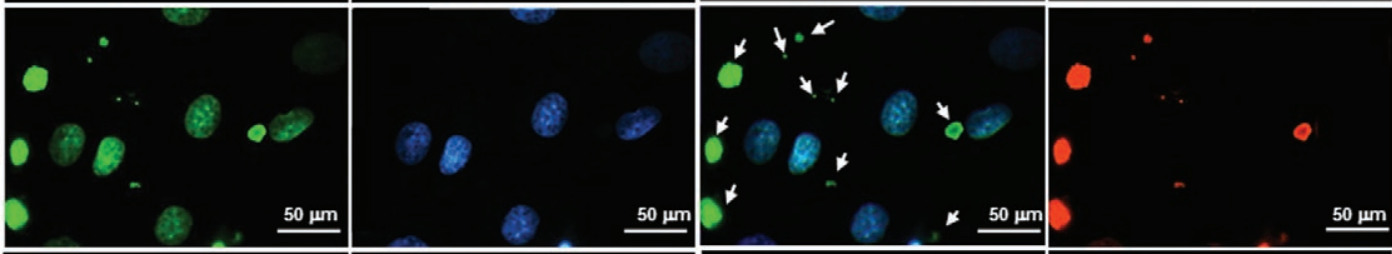

$6 \mathrm{~h}$
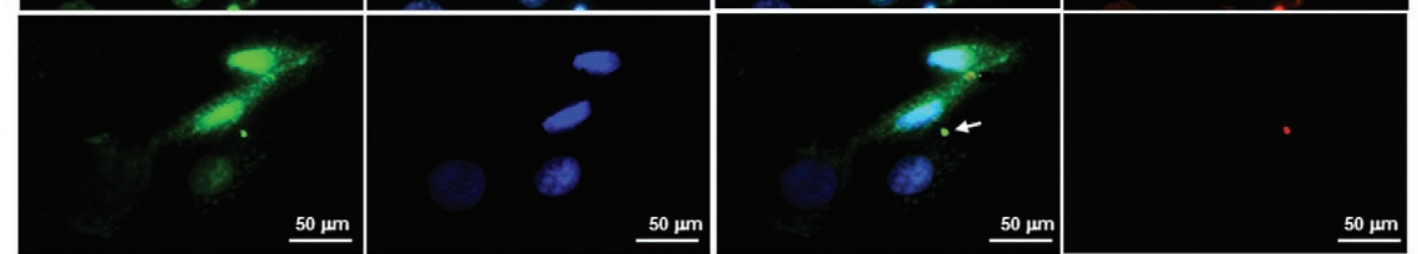

$12 \mathrm{~h}$
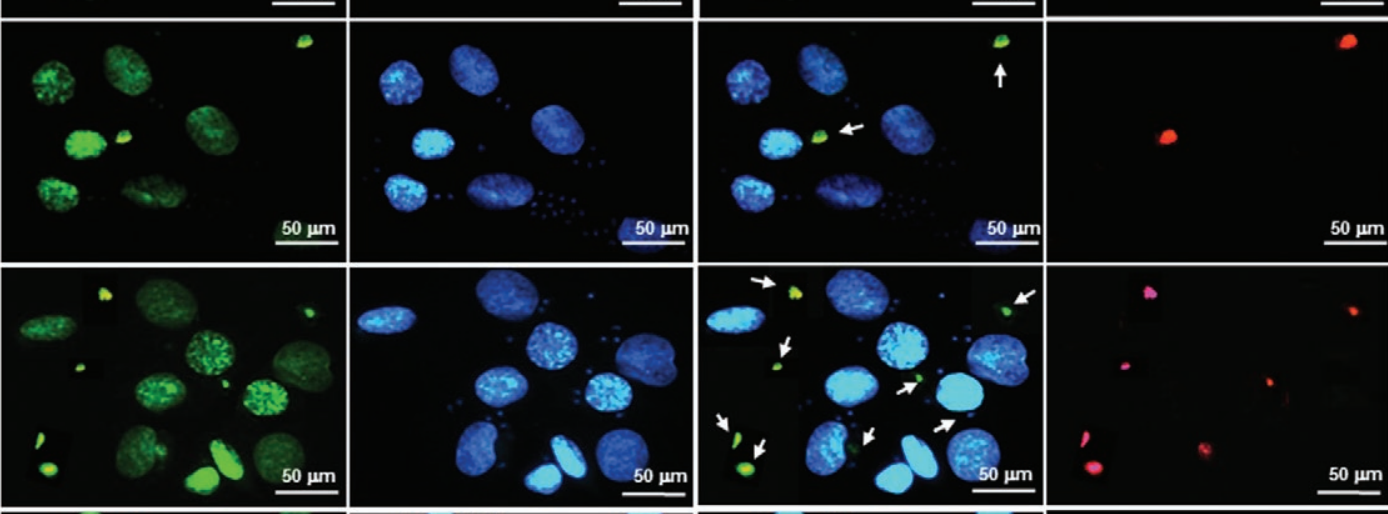

$24 \mathrm{~h}$
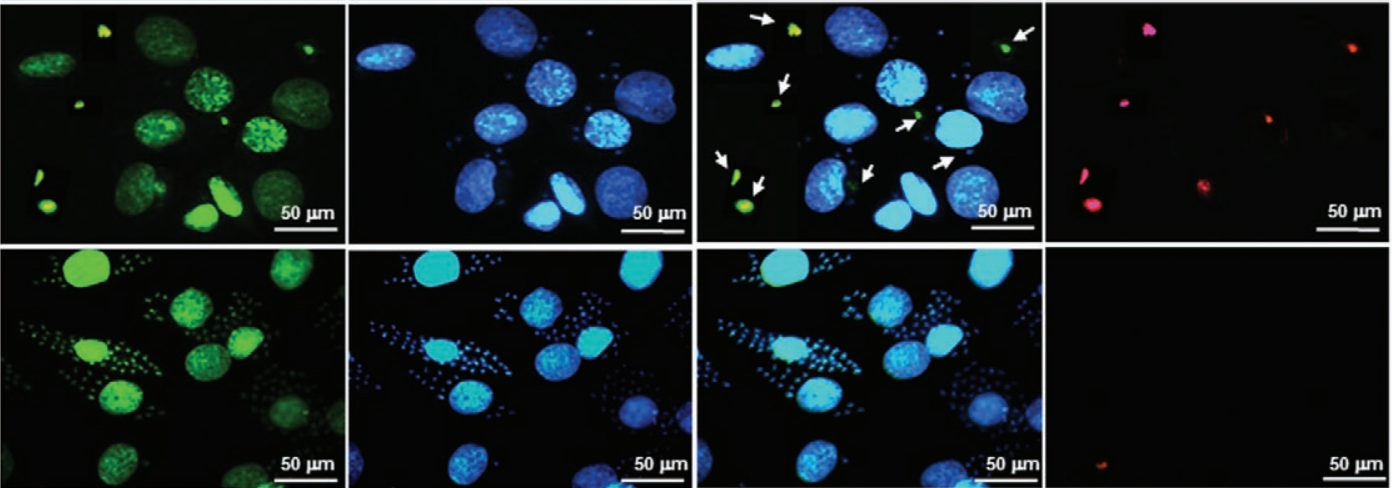

Fig. 4: Trypanosoma cruzi elicits modulatory effects on the activity and cellular distribution of the cyclooxygenase-2 (COX-2) protein. A: COX-2 activity in infected and uninfected (U) cells. An oscillatory effect on COX-2 activity is observed during $48 \mathrm{~h}$ of parasite cellular infection; B: fluorescence microscopy analyses of the COX-2 distribution in H9c2-infected and U cells. The COX-2 protein (fluorescein isothiocyanate labelled) localised preferentially to the nucleus [4,6 diamino-2-phenylindole (DAPI) labelled] and in cytoplasmic granules (arrowheads), whose intensity depends on the COX-2 inactivation pattern. The positive co-immunostaining of such granules with the eukaryotic initiation factor (eIF4G) characterised them as stress granules. Bars $=50 \mu \mathrm{m}$. Error bars represent the standard deviation of the mean from three independent experiments. ANOVA testing showed significant differences between the control and cell samples and was set at $\mathrm{p}<0.001(* * *)$. 


\section{DISCUSSION}

T. cruzi infection induces multiple responses in the heart that are necessary for successful establishment of infection (Burleigh 2005, Yoshida 2006, Mott et al. 2009). Inflammation is one of the signature events during chagasic cardiomyopathy; however, obtaining a mechanistic understanding of this pathological process is still the focus of several scientific investigations. In this study, we verified the presence of subtle pro-inflammatory stimuli in H9c2 cells after early cellular invasion by the parasite and a correlation between the presence of the parasite and COX-2 protein activity was observed. Even in the initial acute phase, the regulated production of eicosanoids and other pro-inflammatory mediators assures $T$. cruzi survival in host cells, as has been suggested in the late phase of chronic disease (Ashton et al. 2007).

To understand the modulatory effect of the parasite on COX-2 in the early parasitic cellular interaction, IL-1 $\beta$ and PGE2 metabolites produced by H9c2-infected cells were measured. Our data demonstrated an increased level of this cytokine in infected cells, when compared to the uninfected cellular culture, which is supposed to initiate the production of eicosanoids in the investigated assays (Fig. 1B). In parallel, PGE2, which is considered a key regulator of pathogenesis during T. cruzi infection (Ashton et al. 2007), considerably reduces its level in infected cells when compared to the uninfected ones. PGE2 has been found to favour the development of cardiac fibrosis and functional organ deficits following $T$. cruzi infection in in vivo assays at chronic stage of Chagas disease (Cardoni \& Antúnez 2004). However, in these initial steps of the parasitic cellular interaction, the reduced level of this prostanoid may prevent further injuries to the cells, such as a burst of inflammatory signalling that could induce apoptotic processes. This observation is supported by cellular mechanisms, which are modulated by the presence of parasite as changes in COX-2 level, activity and cellular distribution (Figs 2-4). Despite an increased level of COX-2 protein at $2 \mathrm{~h}$ of parasite infection (Fig. 2), when compared to the uninfected culture, PGE2 drastically reduced its level (Fig. 1), at same time the protein activity is reduced (Fig. 4) and COX-2 molecules (mRNA and protein) (Figs 3, 4) were found distributed in SGs. As reviewed by Misteli (2001), SGs are structures that play functional roles in biological processes as diverse as pre-mRNA splicing, translation and mRNA degradation and/or serve as a dynamic storage site for proteins and transcripts to be re-used for translation upon recovery from stress (Misteli 2001, McInerney et al. 2005, Mazroui et al. 2007). The modulatory activity of COX-2 in the next analysed time-points of parasite infection could be explained by the cellular requirement of a minimal amount of COX-2 protein to keep the inner homeostasis, controlling the development of a pro-inflammatory environment and the assembly of the SG structures collaborates with this mechanism. The parasite needs to establish an ideal environment in its host to allow its survival and proliferation during this initial and critical process in cellular infection.
COX-2 induction is considered a key step in the synthesis of prostanoids in response to an exogenous stimulus. It is assumed that the presence of IL-1 $\beta$ in H9c2-infected cultures is able to stimulate COX-2 production during the $48 \mathrm{~h}$ of infection, which could maintain a high level of prostanoids production. Surprisingly, this phenomenon was not observed and we then sought to investigate specific characteristics of COX-2 activity. We began our analysis by studying the correlation between Cox-2 and CUGBP2, considering the observations of Cunha-Neto et al. (2005). In addition Murmu et al. (2004) describes that PGE2 is able to modulate CUGBP2 in the controlling of apoptosis, which is an advantage to the parasite-infected cells. Our findings demonstrated that in the presence of the parasite, Cox-2 mRNA was highly expressed at early time-points after the initial interaction and returned to close to basal levels after $48 \mathrm{~h}$ of parasitic infection (Fig. 2). The same expression pattern was observed for COX-2 protein; however, the amount of protein produced was lower than the observed mRNA, which could be explained by the existence of post-transcriptional mechanisms that help control the protein synthesis.

The analyses of the CUGBP2 protein and it transcripts showed that the highest expression of those molecules were delayed by one time-point compared with COX-2 expression, which could be explained by the close connection between the two proteins (Mukhopadhyay et al. 2003a, b, Murmu et al. 2004, Xu et al. 2007, Moraes et al. 2013). Considering that CUGBP2 binds to the 3'-UTR of Cox-2 mRNA, we investigated the cellular distribution of these molecules using fluorescence microscopy (Fig. $3 \mathrm{~A})$. The analyses demonstrated that CUGBP2 preferentially localises to the cell nucleus and its shuffling to the cytoplasm is correlated with the Cox-2 mRNA distribution. Several studies have demonstrated that the CUGBP2 distribution is dependent on its phosphorylation status (Roberts et al. 1997, Savkur et al. 2001, Timchenko et al. 2001). In our assay, after cellular infection with the T. cruzi Y strain, a controlled pro-inflammatory environment was established. In this cellular environment, a fraction of CUGBP2 shuffled to the cytoplasm and resided in cytoplasmic SGs, considering the positive coimmunostaining with the eIF4G antibody. Based on the above observations, once Cox-2 mRNA is transcribed in higher levels it is sequestered by the CUGBP2 protein to SGs. The protein acts as a co-factor in translational blockage, as described by Mukhopadhyay et al. (2003a), and at the same time, it cooperates in decreasing the mRNA level of Cox-2 by facilitating its processing and degradation, which collaborates with the controlling of the pro-inflammatory environment. In addition, the physical interaction between the above two molecules were corroborated by the Co-IP analyses, followed by the formaldehyde RNA cross-linking assays, which allowed the detection of Cox-2 mRNA and CUGBP2 protein interaction (Fig. 3B). Based on such observations, the delayed expression of CUGBP2, when compared to the pattern of COX-2 expression, could be explained by its translocation to $\mathrm{SG}$, which drives the cell to increase CUGBP2 production. The relevance of CUGBP2 to cell 
A
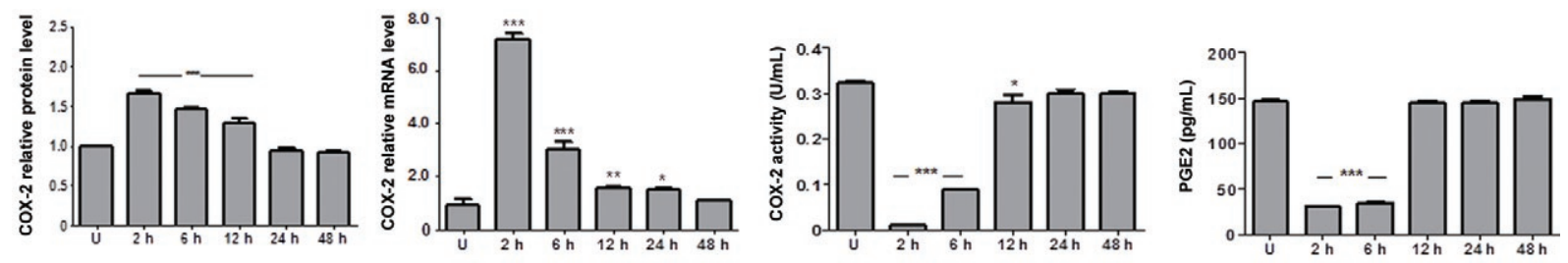

B
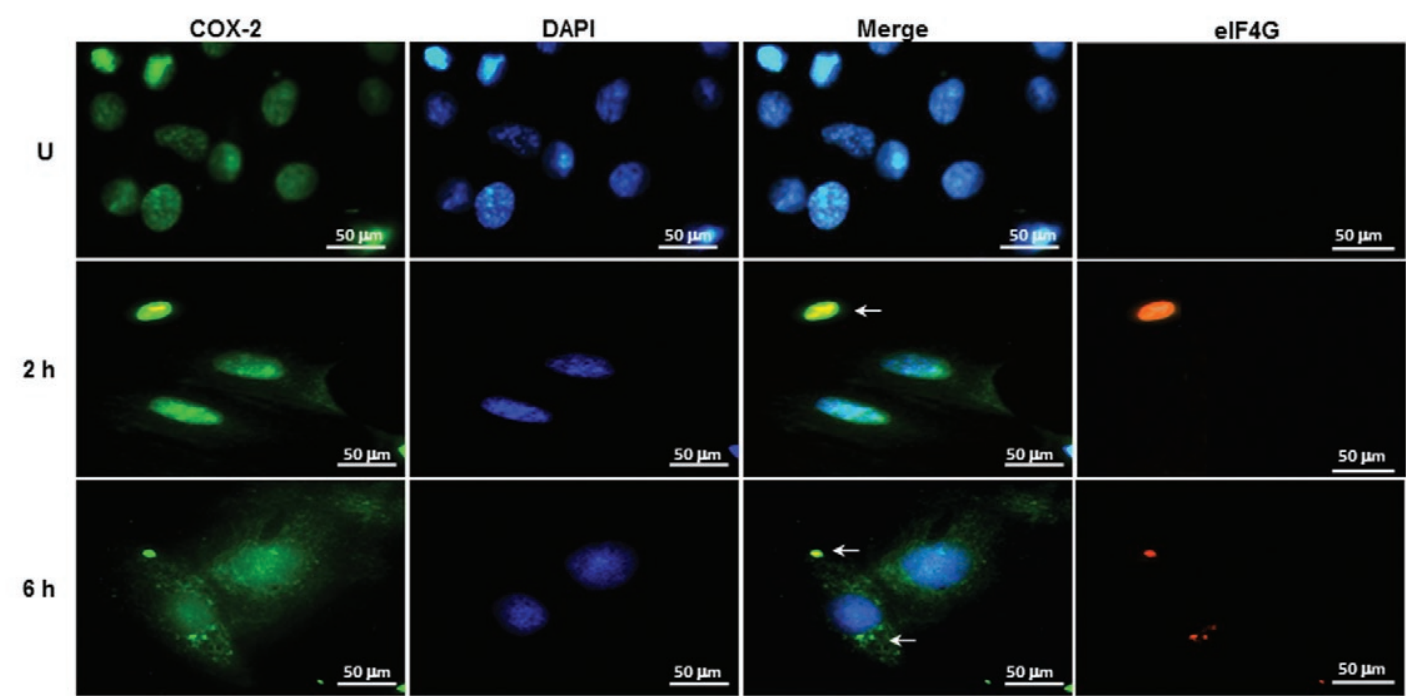

Fig. 5: the inhibitory effect of NS-398 on cyclooxygenase-2 (COX-2) modulates the protein activity and distribution in H9c2 uninfected (U) cells, as Trypanosoma cruzi infection does in infected cells. A: cells were treated or U with NS-398 chemical for up to $48 \mathrm{~h}$ and COX-2 correlated molecules were measured [COX-2 protein and mRNA, COX-2 activity and prostaglandin E2 (PGE2) production]. The results of three independent experiments were quantified and plotted in graphs. ANOVA testing showed significant differences between the control and treated cell samples. The level of significance was set at $\mathrm{p}<0.05(*), \mathrm{p}<0.01\left(^{* *}\right)$ and $\mathrm{p}<0.001(* * *)$; B: fluorescence microscopy analyses of H9c2 treated cells and U with NS-398. The two time-points with significative changes in COX-2 behaviour when compared to the U cells were presented at B. COX-2 protein (fluorescein isothiocyanate labelled) localised preferentially at the nucleus [4,6 diamino-2-phenylindole (DAPI) labelled] and co-localises with cytoplasmic stress granules, as corroborated by the co-immunostaining with the eukaryotic initiation factor (eIF4G) and indicated by arrowheads in the cells. Bars $=50 \mu \mathrm{m}$.

homeostasis could be verified in negative results of constitutive CUGBP2 gene silencing, which drives cell death (Moraes et al. 2013) and which reinforced the molecular function of CUGBP2 in the controlling of apoptosis (Murmu et al. 2004) which is favoured by the low PGE2 level found in H9c2 parasite-infected cells. The relevant molecular mechanisms of CUGBP2 in the context of Chagas disease was never addressed and it could explain the previous results of Cunha-Neto et al. (2005) that showed increased expression of CUGBP2 RNA

In the presence of the parasite, the activity of the COX-2 enzyme had an interesting oscillatory pattern (Fig. 4A). Down-regulation of COX-2 protein activity could be achieved via a transient interaction of specific molecules with the catalytic domain of the COX-2 protein. COX-2 exhibits a hydrophobic tunnel, which allows binding of AA to be metabolised and a possible interaction with a different molecule could inhibit COX-2 activity. In addition, the molecular networks triggered by the parasites in $\mathrm{H} 9 \mathrm{c} 2$ cells are able to activate various kinases and phosphatases, which may be responsible for transient phosphorylation of the COX-2 protein. The dynamic changes in the COX-2 protein could result in its unfolding and inactivation. This hypothesis could be supported by the localisation of COX-2 in larger cytoplasmic granules at the time-point that most COX-2 is in its inactivated state (Fig. 4B). Reinforcing this observation, analysis of the COX-2 sequence using the NetPhos 2.0 Server (Blom et al. 1999) it was possible predicted 32 phosphorylation sites in the protein sequence (Ser: 13, Thr: 10 and Tyr: 9) of Rattus norvegicus (data not shown). Future studies will investigate the major kinases that could be directly responsible for this COX-2 molecular inactivation.

To corroborate previous observation on COX-2 activity and cellular distribution in H9c2 cells, NS-398 was added to the uninfected cultures (Fig. 5). This selective COX-2 inhibitor was the first in a series of isoform-selective drugs designed to preferentially inhibit COX-2, with the aim of ameliorating many of the toxic gastrointestinal side effects caused by regularly prescribed nonsteroidal anti-inflammatory drugs. This drug creates a stressful environment that modulates COX-2 expression and behaviour in the investigated cells. Pronounced effects on COX-2 were observed at the $2 \mathrm{~h}$ and $6 \mathrm{~h}$ time-points. At 
$2 \mathrm{~h}$ time-point the increased expression of Cox-2 mRNA could be correlated with the immediate inhibitory effect of the drug on COX-2 protein activity (Fig. 5A) and its cellular trafficking to the cytoplasmic SG (Fig. 5B). Based on such observations we can suggest that the inhibitory effect of NS-398 on COX-2 activity influences gene expression and the protein cellular distribution in uninfected H9c2 cells as occurred in parasite-infected cells. At $6 \mathrm{~h}$ treatment, the drug still quite functional and able to modulate COX-2 activity and PGE2 production in treated cells. However, the decrease in SG size at $6 \mathrm{~h}$ time-point could be connected to the mRNA turnover rates of Cox-2 mRNA and protein (Mbonye et al. 2006, Mbonye \& Song 2009) and also connected with the recovery of COX-2 protein activity, suggesting that it left the SG (Fig. 5B).

Transient inhibition of COX-2 activity could be proposed as an evolutionary mechanism that facilitates parasite survival in the very early stage of Trypanosoma cellular interactions. The T. cruzi interaction with and infection of cells are critical steps in the survival of the parasite in the host and for the establishment of the disease. In the present study, an oscillatory pattern of COX-2 was observed to contribute to the control of cellular metabolism by the parasite. Molecular signalling in cell culture regulates the mRNA level of Cox-2 via its degradation and modulates COX-2 protein defolding and inactivation, which controls the production of metabolites, facilitating the establishment of the disease and the evasion of cell death mechanisms. In all this molecular signalling network, SG structures assemble works in synchrony with the cellular environment. Further investigations will be performed to describe the molecules that control the transient inactivation of COX-2 in T. cruzi-infected cells.

\section{REFERENCES}

Abdalla GK, Faria GE, Silva KT, Castro EC, Reis MA, Michellin MA 2008. Trypanosoma cruzi: the role of PGE2 in immune response during the acute phase of experimental infection. Exp Parasitol 118: 514-521.

Ashton AW, Mukherjee S, Nagajyothi FN, Huang H, Braunstein VL, Desruisseaux MS, Factor SM, Lopez L, Berman JW, Wittner M, Scherer PE, Capra V, Coffman TM, Serhan CN, Gotlinger K, Wu KK, Weiss LM, Tanowitz HB 2007. Thromboxane A2 is a key regulator of pathogenesis during Trypanosoma cruzi infection. $J$ Exp Med 204: 929-940.

Blom N, Gammeltoft S, Brunak S 1999. Sequence and structurebased prediction of eukaryotic protein phosphorylation sites. $J$ Mol Biol 294: 1351-1362.

Borges DC, Araújo NM, Cardoso CR, Chica JEL 2013. Different parasite inocula determine the modulation of the immune response and outcome of experimental Trypanosoma cruzi infection. Immunology 138: 145-156.

Burleigh BA 2005. Host cell signaling and Trypanosoma cruzi invasion: do all roads lead to lysosomes? Sci STKE 2005: 36.

Burleigh BA, Soldati D 2008. Molecular mechanisms of parasite invasion. Subcellular Biochemistry 47, Springer Science \& Business Media, New York, 257 pp.

Burleigh BA, Woolsey M 2002. Cell signalling and Trypanosoma cruzi invasion. Cell Microbiol 4: 701-711.

Calvet CM, Melo TG, Garzoni LR, Oliveira Jr FO, Silva-Neto DT, Meirelles MNSL, Pereira MCS 2012. Current understanding of the Trypanosoma cruzi-cardiomyocyte interaction. Front Immunol 3: 327.
Cardoni RL, Antúnez MI 2004. Circulating levels of cyclooxygenase metabolites in experimental Trypanosoma cruzi infections. Mediators Inflamm 13: 235-240.

Corral RS, Guerrero NA, Cuervo H, Gironès N, Fresno M 2013. Trypanosoma cruzi infection and endothelin-1 cooperatively activated pathogenic inflammatory pathways in cardiomyocytes. PLOS Negl Trop Dis 7: e2034.

Cunha-Neto E, Dzau VJ, Allen PD, Stamatiou D, Benvenutti L, Higuchi ML, Koyama NS, Silva JS, Kalil J, Liew CC 2005. Cardiac gene expression profiling provides evidence for cytokinopathy as a molecular mechanism in Chagas disease cardiomyopathy. Am J Pathol 167: 305-313.

Freire-de-Lima CG, Nascimento DO, Soares MB, Bozza PT, CastroFaria-Neto HC, de Mello FG, DosReis GA, Lopes MF 2000. Uptake of apoptotic cells drives the growth of a pathogenic trypanosome in macrophages. Nature 403: 199-203.

Gareau C, Fournire MJ, Filion C, Coudert L, Martel D, Labelle Y, Mazroui R 2011. p21(WAF1/CIP1) upregulation through the stress granule-associated protein CUGBP1 confers resistance to bortezomib-mediated apoptosis. PLoS ONE 6: e20254.

Haeggstrom JZ, Rinaldo-Matthis A, Wheelock CE, Wetterholm A 2010. Advances in eicosanoid research, novel therapeutic implications. Biochem Biophys Res Commun 396: 135-139.

Huang H, Chan J, Wittner M, Jelicks LA, Morris SA, Factor SM, Weiss LM, Braunstein VL, Bacchi CJ, Yarlett N, Chandra M, Shirani J, Tanowitz HB 1999. Expression of cardiac cytokines and inducible form of nitric oxide synthase (NOS2) in Trypanosoma cruzi-infected mice. J Mol Cell Cardiol 31: 75-88.

Kabututu Z, Martin SK, Nozaki T, Kawazu S, Okada T, Munday CJ, Duszenko M, Lazarus M, Thuita LW, Urade Y, Kubata BK 2003. Prostaglandin production from arachidonic acid and evidence for a 9,11-endoperoxide prostaglandin $\mathrm{H} 2$ reductase in Leishmania. Int J Parasitol 33: 221-228.

Kedersha N, Stoecklin G, Ayodele M, Yacono J, Lykke-Andersen J, Fritzler MJ, Scheuner D, Kaufman RJ, Golan DE, Anderson P 2005. Stress granules and processing bodies are dynamically linked sites of mRNP modeling. J Cell Biol 169: 871-884.

Kim MJ, Kim HS, Lee SH, Yang Y, Lee MS, Lim JS 2014. NDRG2 controls COX-2/PGE2-mediated breast cancer cell migration and invasion. Mol Cells 37: 759-765.

Kimes BW, Brandt BL 1976. Properties of a clonal muscle cell line from rat heart. Exp Cell Res 98: 367-381.

Kubata BK, Kabututu Z, Nozaki T, Munday CJ, Fukuzumi S, Ohkubo K, Lazarus M, Maruyama T, Martin SK, Duszenko M, Urade Y 2002. A key role for old yellow enzyme in the metabolism of drugs by Trypanosoma cruzi. J Exp Med 196: 1241-1251.

Kwak HJ, Park KM, Choi HE, Lim HJ, Park JH, Park HY 2010. The cardioprotective effects of zileuton, a 5-lipoxygenase inhibitor, are mediated by COX-2 via activation of PKC $\delta$. Cell Signal 22: 80-87.

Livore VI, Tripodi KE, Uttaro AD 2007. Elongation of polyunsaturated fatty acids in trypanosomatids. FEBS J 274: 264-274.

Lu B, Choy PC 2004. Modulation of arachidonic acid metabolism by phorbol 12-myristate 13-acetate in monocytes and myocytes. In NS Dhalla, H Rupp, A Angel, GN Pierce (eds.), Pathophysiology of cardiovascular disease, Kluwer Academic Publishers, Boston, p. 329-340.

Machado FS, Mukherjee S, Weiss LM, Tanowitz HB, Ashton AW 2011. Bioactive lipids in Trypanosoma cruzi infection. Adv Parasitol 76: 1-31.

Mazroui R, Di Marco S, Kaufman RJ, Gallouzi IE 2007. Inhibition of the ubiquitin-proteasome system induces stress granule formation. Mol Biol Cell 18: 2603-2618. 
Mbonye UR, Song I 2009. Posttranscriptional and posttranslational determinants of cyclooxygenase expression. BMB Rep 42: 552-560.

Mbonye UR, Wada M, Rieke CJ, Tang HY, Dewitt DL, Smith WL 2006. The 19-amino acid cassette of cyclooxygenase-2 mediates entry of the protein into the endoplasmic reticulum-associated degradation system. J Biol Chem 281: 35770-35778.

McInerney GM, Kedersha NI, Kaufman RJ, Anderson P, Liljeström P 2005. Importance of eIF2alpha phosphorylation and stress granule assembly in alphavirus translation regulation. Mol Biol Cell 16: $3753-3763$.

Meyer-Siegler K 2001. COX-2 specific inhibitor, NS-398, increases macrophage migration inhibitory factor expression and induces neuroendocrine differentiation in $\mathrm{C} 4-2 \mathrm{~b}$ prostate cancer cells. Mol Med 7: 850-860.

Misteli T 2001. Protein dynamics: implications for nuclear architecture and gene expression. Science 291: 843-847.

Moraes KCM, Monteiro CJ, Soares CP 2013. A novel function for CUGBP2 in controlling the pro-inflammatory stimulus in H9c2 cells: subcellular trafficking of messenger molecules. Cell Biol Int 37: 1129-1138.

Mott A, Lenormand G, Costales J, Fredberg JJ, Burleigh B 2009. Modulation of host cell mechanics by Trypanosoma cruzi. J Cell Physiol 218: 315-322.

Mukherjee S, Machado FS, Huang H, Oz HS, Jelicks LA, Prado CM, Koba W, Fine EJ, Zhao D, Factor SM, Collado JE, Weiss LM, Tanowitz HB, Ashton AW 2011. Aspirin treatment of mice infected with Trypanosoma cruzi and implications for the pathogenesis of Chagas disease. PLOS ONE 6: e16959.

Mukhopadhyay D, Houchen CW, Kennedy S, Dieckgraefe BK, Anant $\mathrm{S}$ 2003a. Coupled mRNA stabilization and translational silencing of cyclooxygenase- 2 by a novel RNA binding protein CUGBP2. Mol Cell 11: 113-126.

Mukhopadhyay D, Jung J, Murmu N, Houchen CW, Dieckgraefe BK, Anant S 2003b. CUGBP2 plays a critical role in apoptosis of breast cancer cells in response to genotoxic injury. Ann NY Acad Sci 1010: 504-509.

Murmu N, Jung J, Mukhopadhyay D, Houchen CW, Riehl TE, Stenson WF, Morrison AR, Arumugam T, Dieckgraefe BK, Anant S 2004. Dynamic antagonism between RNA-binding protein CUGBP2 and cyclooxygenase-2-mediated prostaglandin E2 in radiation damage. Proc Natl Acad Sci USA 101: 13873-13878.

Petersen CA, Burleigh BA 2003. Role for interleukin-1 $\beta$ in Trypanosoma cruzi - induced cardiomyocyte hypertrophy. Infect Immun 71: 4441-4447.

Prior-Curtis P 2004. The eicosanoids, Johns Wiley \& Sons, England, $655 \mathrm{pp}$.
Roberts R, Timchenko NA, Miller JW, Reddy S, Caskey LT, Swanson MS, Timchemko LT 1997. Altered phosphorylation and intracellular distribution of a (CUG)n triplet repeat RNA-binding protein in patients with myotonic dystrophy and in myotonim protein kinase knockout mice. Proc Natl Acad Sci USA 94: 13221-13226.

Sage L, Hambrey PN, Wechola GM, Mellors A, Tizard IR 1981. Lysiphospholipase 1 in Trypanosoma brucei. Tropenmed Parasitol 32: $215-220$.

Sakane KK, Monteiro CJ, Silva W, Silva AR, Santos PM, Lima KF, Moraes KCM 2014. Cellular and molecular studies of the effects of a selective COX-2 inhibitor celecoxib in the cardiac cell line $\mathrm{H} 9 \mathrm{c} 2$ and their correlation with death mechanisms. Braz J Med Biol Res 47: 50-59.

Sambrook J, Fritsch EF, Maniatis T 2001. Molecular cloning: a laboratory manual, 3rd ed., Cold Spring Harbor, New York, 1626 pp.

Savkur RS, Pjilip AV, Cooper TA 2001. Aberrant regulation of insulin receptor alternative splicing is associated with insulin resistance in myotonic dystrophy. Nat Genet 29: 40-47.

Sharma J, Eickhoff CS, Hoft DF, Ford DA, Gross RW, McHowat J 2013. The absence of myocardial calcium-independent phospholipase A2 $\gamma$ results in impaired prostaglandin E2 production and decreased survival in mice with acute Trypanosoma cruzi infection. Infect Immun 87: 2278-2287.

Steinberg SF 2000. Many pathways to cardiac hypertrophy. $J \mathrm{Mol}$ Cell Cardiol 32: 1381-1384.

Sterin-Borda L, Gorelik G, Goren N, Cappa SG, Celentano AM, Borda E 1996. Lymphocyte muscarinic cholinergic activity and PGE2 involvement in experimental Trypanosoma cruzi infection. Clin Immunol Immunopathol 81: 122-128.

Taneja KL 1998. Localization of trinucleotide repeat sequences in myotonic dystrophy cells using a single fluorochrome-labeled PNA probe. Biotechniques 24: 472-476.

Timchenko NA, Cai ZJ, Welm AL, Reddy S, Ashizawa T, Timchenko LT 2001. RNA CUG repeats sequester CUGBP1 and alter protein levels and activity of CUGBP1. J Biol Chem 276: 7820-7826.

WHO - World Health Organization 2013. Chagas disease (American trypanosomiasis). Available from: who.int/mediacentre/factsheets/fs340/en/.

Xu K, Kitchen CM, Shu H-KG, Murphy T 2007. Platelet-derived growth factor-induced stabilization of cyclooxygenase 2 mRNA in rat smooth muscle cells requires the c-Src family of proteintyrosine kinases. J Biol Chem 282: 32699-32709.

Yoshida N 2006. Molecular basis of mammalian cell invasion by Trypanosoma cruzi. An Acad Bras Cienc 78: 87-111.

Zhang L, Tarleton RL 1999. Parasite persistence correlates with disease severity and localization in chronic Chagas disease. J Infect Dis 180: 480-486. 